Aksiologiya: Jurnal Pengabdian Kepada Masyarakat

Vol.4, No.2, Agustus $2020 \mathrm{Hal} 231$ - 240

ISSN 2528-4967 (print) dan ISSN 2548-219X (online)

\title{
Pemberdayaan Ibu-Ibu Rumah Tangga Dalam Upaya Meningkatkan Ekonomi Keluarga Melalui Pengelolaan Usaha Rumahan di Tangerang Selatan
}

\author{
Esust Setiawati ${ }^{1}$, Siti Rozinah ${ }^{2}$ \\ 1,2Institut Teknologi dan Bisnis Ahmad Dahlan Jakarta \\ Email: esustfirta@gmail.com¹; sitirozinah@gmail.com²
}

\begin{abstract}
ABSTRAK
Keberdayaan kaum perempuan di bidang ekonomi adalah salah satu indikator meningkatnya kesejahteraan. Kaum perempuan juga mempunyai andil besar dalam kegiatan penanggulangan kemiskinan melalui pemberdayaan masyarakat. Salah satunya kaum perempuan dapat meningkatkan kesejahteraan keluarganya dengan melakukan kegiatan usaha produktif rumah tangga, dengan memproduksi dan menjual makan rumahan. Peluang bisnis makanan rumahan masih terbuka karena makanan rumahan merupakan makanan pokok masyarakat, dimana makanan tersebut dibutuhkan setiap saat. Bisnis makanan rumahan tidak terlalu sulit dilakukan, karena ibu-ibu rumah tangga dapat melakukan kegiatan produksi atau memasak sekaligus untuk keluarganya dan bahan bakunya mudah diperoleh di pasar-pasar tradisional. Kegiatan pengabdian masyarakat ini, bertujuan untuk (1) memanfaatkan potensi ibu rumah tangga untuk memperoleh penghasilan tambahan guna menopang ekonomi keluarga. (2) Meningkatkan perekonomian/kesejahteraan keluarga. Luaran kegiatan pengabdian masyarakat ini adalah Ibu-ibu Rumah Tangga RW 04, Kelurahan Pisangan Timur, Cirendeu, dapat memperbaiki manajemen usaha dan mencari peluang usaha yang dapat dilakukan dari rumah tanpa harus meninggalkan keluarga.
\end{abstract}

Kata Kunci : Pemberdayaan, ibu Rumah Tangga, Usaha Rumahan, Ekonomi Keluarga

\section{Empowerment Of Household Mothers In Efforts To Improve The Family Economy Through Management Of Home Business In South Tangerang}

\begin{abstract}
The success of women in the economic field is one indicator of welfare. Women also have a big role in poverty alleviation activities through community empowerment. One of them is women can improve welfare by carrying out household business activities, by producing and selling home. Home-based food business opportunities are still open because home-based food is community food, where food is needed all the time. Home-based food business is not too difficult to do, because housewives can do production or cooking activities at the same time for agriculture and raw materials are easily obtained in traditional markets. This community service activity aims to (1) utilize the potential of households to obtain additional benefits to support the family's economy. (2) Improve family finances / welfare. The outputs of community service activities are Housewives of RW 04, Kelurahan Pisangan Timur, Cirendeu, can improve business management and look for business opportunities that can be done from home without having to open a family.
\end{abstract}

Keywords: Empowerment, Family Economy, Housewife, Home Business. 


\section{PENDAHULUAN}

Kaum perempuan yang memiliki kemampuan mandiri di bidang ekonomi adalah salah satu indikator meningkatnya kesejahteraan. Saat kaum perempuan menjadi kaum terdidik, mempunyai hak-hak kepemilikan, dan bebas untuk bekerja di luar rumah maupun di dalam rumah serta mempunyai pendapatan mandiri, hal ini merupakan tanda kesejahteraan rumah tangga meningkat. Selain itu, kaum perempuan juga mempunyai andil besar dalam kegiatan penanggulangan kemiskinan melalui pemberdayaan masyarakat. Salah satu contoh, bahwa kaum perempuan dapat meningkatkan kesejahteraan keluarganya dengan melakukan kegiatan usaha produktif rumah tangga, seperti memproduksi dan menjual lauk pauk, makanan untuk sarapan, kue-kue jajan pasar dan lainlain, dan didalam laporan ini kami menyebut dengan makanan rumahan. Peluang bisnis makanan rumahan masih terbuka karena merupakan makanan pokok masyarakat, dimana makanan tersebut dibutuhkan setiap saat. Bisnis makanan rumahan tidak terlalu sulit dilakukan, karena ibuibu rumah tangga dapat melakukan kegiatan produksi atau memasak sekaligus untuk keluarganya dan bahan bakunya mudah diperoleh di pasarpasar tradisional. Namum jika ingin bisnis tersebut berkembang pelaku bisnis harus mampu menjaga kualitas dan rasa makanan, memperhatikan cara pengolahan makanannya, serta melakukan manajemen usaha dengan benar.
Letak RW 04 yang berada dilingkungan Pisangan Timur, Kelurahan Cirendeu terletak kurang lebih $3 \mathrm{Km}$ dari Kampus ITB Ahmad Dahlan. Ibu-Ibu rumah tangga usia produktif di RW 04 Kelurahan Pisangan Timur, Cirendeu berjumlah kurang lebih 100 orang, dan saat ini yang menjalankan usaha rumahan berupa produksi makanan siap saji dan kue jajan pasar berjumlah 25 orang. Saat ini usaha tersebut masih dikelola seadanya, setiap ibu rumah tangga memproduksi makanan rumahan dan memasarkan sendirisendiri di teras rumahnya, bahkan pengelolaan keuangannya pun masih tercampur dengan keuangan keluarga. Dilihat dari aspek pasar dan pemasaran, bisnis makanan rumahan ini memiliki prospek yang baik, karena diling-kungan RW 04 banyak perumahan-perumahan yang baru berdiri, tempat tinggal sementara (kos-kosan) untuk pendatang dan banyak berdiri perguruan tinggi seperti Universitas Muhammadiyah Jakarta, ITB AD Jakarta, Universitas Islam Negeri Syarief Hidayatullah dan lain-lain, yang perkembangan jumlah mahasiswanya sangat pesat. Sebagian besar mahasiswa dan karyawan dari perguruan tinggi tersebut tinggal sementara (kost) di lingkungan RW 04 Pisangan Timur, Kelurahan Cirendeu, dan mereka membutuhkan makanan pokok setiap hari. Dari sisi manajemen usaha, mitra belum melakukan manajemen usaha karena belum memahami pentingnya mana-jemen usaha. Manajemen usaha disini terdiri dari manajemen 
produksi, manajemen pemasaran dan manajemen keuangan.

Berdasarkan analisis situasi diatas, masalah yang dihadapi oleh mitra adalah sebagai berikut. (a) Pemasaran, bisnis atau usaha mitra belum memiliki merek atau nama tempat usaha, hal ini akan menyulitkan konsumen mencari tempat usaha atau warungnya, karena dilingkungan RW 04 banyak berdiri tempat usaha sejenis, dan mitra masih melaku-kan pemasaran produknya sendiri-sendiri. (b) Produksi makanan, mitra masih belummemahanipentingnyakesehatan dan keamanan pangan, terutama pada saat memasarkan makanan, mitra menjajakan/ mendisplay makanan masih menggunakan alas kertas koran dan terbuka, sehingga makanan masih sangat mudah terkon-tamisasi kotoran. (c) Manajemen keuangan, mitra belum memahami pentingnya manajemen keuangan, mitra saat belum memisahkan keuangan keluarga dengan keuangan usaha dan belum melakukan pencatatan, dalam hal menentukan prioritas penyelesaian masalah yang dihadapi oleh mitra, maka pengusul bersama mitra melaku-kan kesepakatan dalam pelaksa-naan kegiatan pengabdian kepada masyarakat ini, adalah: (i) Pemberian wawasan kewirausahaan terutama dalam pengembangan bisnis dan mencari peluang usaha. (ii) Pendampingan manajemen usahayang terdiri dari manajemen pemasaran, manajemen produksi dan manajemen keuangan.

Kegiatan pengabdian masyarakat ini, bertujuan untuk memanfaatkan potensi ibu rumah tangga untuk memperoleh peng-hasilan tambahan guna menopang kebutuhan rumah tangga dan meningkatkan perekonomian/kesejahteraankeluarga. Kegiatan pengabdian masyarakat ini diharapkandapatmemberikan manfaat terutama bagi pihak-pihak yang terlibat dalam kegiatan ini sebagai berikut. (a) Bagi mitra atau khalayak sasaran dalam hal ini Ibu-ibu Rumah Tangga RW 04, Kelurahan Pisangan Timur, Cirendeu, dapat memberikan pengetahuan untuk berwirausaha dan mengembangkan usaha yang sudah berjalan. (b) Bagi pelaksana, kegiatan ini diharapkan dapat menjadi tempat untuk mengembangkan ilmu pengetahuan sekaligus berkontribusi kepada masyarakat untuk membantu memecahkan permasalahan. Khalayak sasaran dalam kegiatan ini adalah ibu-ibu rumah tangga yang tinggal di RW 04 Pisangan Timur, Kelurahan Cirendeu yang letaknya kurang lebih $3 \mathrm{~km}$ dari Kampus STIE Ahmad Dahlan, Ciputat. Adapun jumlah mitra kegiatan pengabdian kepada masyarakat berjumlah 20 orang.

Menurut Widjaja (2003) pemberdayaan masyarakat adalah upaya meningkatkan kemampuan dan potensi yang dimiliki masyarakat, sehingga masyarakat dapat mewujudkan jati diri, harkat dan martabatnya secara maksimal, untuk bertahan dan mengembangkan diri secara mandiri baik dibidang ekonomi, sosial, agama dan budaya. Pemberdayaan masyarakat merupakan upaya mempersiapkan masyarakat, seiring dengan langkah upaya 
memperkuat kelembagaan masyarakat agar mereka mampu mewujudkan kemajuan, kemandirian dan kesejahteraan dalam suasana keadilan social yang berkelanjutan. (Sumaryadi; 2005)

Pengetahuan kewirausahaan adalah pemahaman seseorang terhadap wirausaha dengan berbagai karakter positif, kreatif dan inovatif dalam mengembangkan peluang-peluang usaha menjadi kesempatan usaha yang menguntungkan dirinya sendiri dan masyarakat atau konsumen. (Kontowicaksono; 2012). Menurut Nurbaya dan Moerdiyanto (2012), pengetahuan kewirausahaan adalah ilmu, seni maupun perilaku, sifat, ciri danwatakseseorangyangmewujudkan gagasan inovatif ke dunia nyata secara kreatif. Sesuai definisi diatas, maka setiap insan yang akan berwirausaha harus memiliki karakter positif, tidak mudah menyerah, kreatif dan inovatif dalam mengembangkan dan mencari peluang usaha. Menurut Chat and Brooks (2015) seorang penulis senior dalam dunia bisnis, kewirausahaan mmerupakan pengembangan sebuah usaha dari bawah keatas, dimulai dari kemunculan ide dan mengubahnya menjadi bisnis yang menguntungkan. Konsep Kewirusahaan tidak saja merupakan ilmu, namun melibatkan seni dan ketrampilan untuk mengelola semua keterbatasn sumber daya, informasi dan dana yang ada, guna mempertahankan hidup, mencari nafkah atau meraih posisi puncak dalam karir. Kunci keberhasilan kedua wirausahawan itu (Warren Buffet dan Bill Gate) dalam sejarah tercatat karena beberapa hal yaitu (1) mempunyaikemauanbelajaryangterus menerus, (2) mempunyai ketabahan dalam menghadapi kegagalan atau tantangan, (3) berani membuat inovasi baru dan tampil beda dengan yang lain, (4) tidak puas dengan setiap hasil usaha yang dilakukan, (5) mempunyai kemampuan beradaptasi, baik dengan lingkungan internal maupun eksternal. Karakteristik wirausaha adalah (1) motivasi untuk berprestasi; (2) Selalu perspektif: Selalu prespektif mencerminkan bahwa seorang wirausahawan harus berfikir, berusaha dan memanfaatkan peluang dengan penuh perhitungan untuk meraih masa depannya secara optimis; (3) memiliki kreativitas (daya cipta) tinggi, berarti mempunyai kemampuan untuk berfikir yang baru dan berbeda; (4) memiliki perilaku inovatif tinggi; (5) memiliki komitmen dalam pekerjaan; (6) memiliki etos kerja dan tanggung jawab; (7) mandiri atau tidak tergantung orang lain; (8) berani menghadapi resiko; (9) selalu mencari peluang; (10) memiliki jiwa kepemimpinan; dan (11) memiliki kemampuan manajerial.

Masyarakat sering menganggap bahwa pemasaran sama dengan penjualan, namun sesungguhnya pemasaran memiliki arti yang lebih luas. Penjualan merupakan bagian dari pemasaran dan merupakan bagian yang penting dari pemasaran itu sendiri. Pemasaran berarti bekerja dengan pasar untuk mewujudkan pertukaran potensial dengan maksud memenuhi kebutuhan dan memuaskan keinginan manusia. Apabila pelaku 
usaha atau pelaku bisnis memberi perhatian lebih banyak pada kegiatan pemasaran, maka usaha atau bisnis tersebut tidak akan kesulitan mengikuti perubahan kebutuhan dan keinginan konsumen, sehingga akan mudah mengenali peluangpeluangnya, karena konsumen akan selalu mencari yang terbaik untuk memenuhi kebutuhan dan keinginannya dan tentu saja dengan harga yang terjangkau dan dengan kualitas yang baik pula. Manajemen Pemasaran menurut Kotler dan Keller adalah seni dan ilmu memilih pasar sasaran dan mendapatkan, menjaga dan menumbuhkan pelanggan dengan menciptakan dan mengkomunikasikan nilai pelanggan yang unggul. Menurut Boone dan Kurtz (2003) dalam Widiyono dan Mukhaer Pakkanna pemasaran adalah proses menemukan keinginan dan kebuutuhan pelanggan dan kemudian menyediakan barang dan jasa yang memenuhi atau melebihi harapan pelanggan. Dalam pengembangan strategi pemasaran ada beberapa aspek yang harus diperhatikan, yaitu sebagai berikut. (1) Produk, (2) Harga, (3) Distribusi/ tempat, (4) Promosi.

Sedangkan konsep pemasaran masyarakat menegaskan bahwa tugas organisasi adalah menentukan kebutuhan, keinginan, dankepentingan pasar sasaran serta memberikan kepuasan yang diinginkan secara lebih efektif dan efisien dibandingkan pesaing dengan cara yang tetap mempertahankan atau meningkatkan kesejahteraan masyarakat dan Konsumen(Kotler, 2005:30). Menurut
Pribadi dan Mundung (2007:26) konsep pemasaran mengandung tiga unsur pokok yaitu: mengarahkan usaha kepada pelayanan keperluan konsumen yang dilayani (menyediakan/menemu-kan barang yang diperlukan), (b) Melaksanakan kegiatan pemasaran yang terpadu dalam usaha mempengaruhi pasar untuk merebut konsumen, (c) mewujudkan kepuasan konsumen dalam upaya menciptakan pelanggan tetap. Menurut Pribadi dan Mundung (2007) mendefinisikan bahwa Konsep pemasaran adalah upaya pemasaran yang berfokus pada pasar dan berorientasi kepada konsumen untuk memberikan kepuasan kepada konsumen sebagai kunci mencapai tujuan perusahaan.

Manajemen keuangan merupakan hal yang penting dalam perusahaan baik perusahaan besar maupun perusahaan kecil, karena manajemen keuangan merupakan pondasi yang kuat untuk pertumbuhan dan perkembangan perusahaan.

Menurut Manulang (2013), mengemukakan manajemen keuangan sebagai berikut. Manajemen keuangan adalah segala kegiatan yang berkaitan dengan aktifitas mencari dana dengan biaya seefiisien mungkin dan menggunakan seefektif mungkin. Manajemen keuangan adalah suatu kegiatan atau aktivitas untuk mendapatkan sumber dana, mengelolanya untuk mendapatkan laba.

Keamanan pangan adalah kondisi dan upaya yang dilakukan untuk mencegah pangan dari kemungkinan 
tiga cemaran, yaitu cemaran biologis, kimia dan benda lain yang dapat mengganggu, merugikan dan membahayakan kesehatan manusia serta tidak bertentangan dengan agama, keyakinan dan budaya masyarakat serta aman dikomsumsi. Pangan olahan yang diproduksi harus sesuai dengan cara pembuatan pangan yang baik. Selain itu pangan yang baik untuk dikonsumsi adalah pangan yang tidak busuk, tidak menjijikkan dan bebas dari cemaran biologi, cemaran kimia dan cemaran fisik. Cemaran Biologi adalah pertumbunhan mikroba yang dapat menyebabkan makanan menjadi busuk, sehingga tidak layak untuk dikonsumsi dan dapat menyebabkan keracunan sampai kematian. Cara pencegahan cemaran biologi adalah (a) beli bahan mentah dan pangan di tempat yang bersih, (b) beli makanan dari penjual yang sehat dan bersih, (c) pilih makanan yang dipajang, disimpan, disajikan dan dikemas dengan baik (d) konsumsi makanan secara benar. Cemaran kimia adalah bahan kimia yang tidak boleh digunakan dalam pangan. Cemaran kimia dapat masuk kedalam pangan dengan sengaja maupun tidak sengaja dan dapat menimbulkan bahaya. Cemaran kimia dapat berupa (a) racun alami misalnya racun ada singkong, ikan yang terpapar merkuri, racun alami pada jengkol dll; (b) racun bahan kimia dari lingkungan misalnya limbah industri, asap kendaraan bermotor, sisa pertisida dari buah dan sayur, detergen, cat/lapisan pada peralatan masak, logam berat dll; (c) penggunaan bahan tambahan yang melebihi takaran, misalnya pemanis, pengawet dan pewarna; (d) penggunan bahan yang dilarang digunakan untuk makanan, misalnya boraks, formalin, rodhamin B dll. Cemaran kimia dapat dicegah melalui (a) selalu memilih bahan makanan yang baik untuk diolah maupun dikomsumsi langsung, (b) mencuci bahan makan sebelum diolah menggunakan air bersih, (c) menggunakan air bersih (tidak tercemar) untuk mengolah makanan, (d) tidak menggunakan bahan tambahan secara berlebihan, (e) tidak menggunakan bahan tambahan yang dilarang untuk makanan, (f) tidak menggunakan peralatan masak yang dilapisi logam berat, (g) tidak menggunakan peralatan kemasan yang tidak aman untuk pangan (Styrofoam, plastik untuk makanan panas/plastik non food grade yang memungkinkan terjadi perpindahan komponen kimia dari wadah ke makanan). Cemaran fisik adalah benda-benda yang tidak boleh ada dalam makanan seperti rambut, batu/kerikil, staples, serangga mati, pecahan kaca dll. Cara pencegahannya cemaran fisik adalah perhatikan sengan seksama makanan yang akan dikonsumsi. Lima kunci keamanan pangan adalah (a) jagalah kebersihan, (b) pisahkan pangan mentah dan pangan matang, (c) memasak pengan dengan benar, (d) jagalah pengan pada suhu aman, dan (e) gunakan bahan pangan yang aman.

\section{METODE PELAKSANAAN}

Usaha mitra masih tergolong pada skala usaha rumahan. Badan 
Pengawasan Obat dan Makanan (BPOM) mengemukakan bahwa usaha rumah tangga adalah suatu perusahaan pangan yang memiliki tempat usaha di tempat tinggal dengan peralatan pengolahan pangan manual hingga semi otomatis. Berdasarkan pengertian dari BPS, menyebutkan bahwa industri kecil dibedakan menjadi 2 (dua), yaitu industri rumah tangga dan pabrik kecil.

Ciri-ciri industri rumah tangga adalah:

1. Jumlah tenaga kerja kurang dari 5 (lima) orang

2. Sebagian besar pekerjanya adalah anggota keluarga sendiri dari pemilik/ pengusaha yang pada umumnya tidak dibayar.

3. Proses produksinya masih manual dan dilakukan di rumah.

4. Produksinya bersifat musiman mengikuti kegiatan di sektor pertanian yang bersifat musiman

5. Jenis produksinya sederhana untuk konsumsi sederhana juga.

Berdasarkan tujuan kegiatan ini, maka tim pengabdian pada masyarakat akanmelakukan pelatihan, penyuluhan dan pendampingan kepada mitra yang sudah memiliki usaha yang menjadi khalayak sasaran kegiatan ini. Dalam kegiatan ini akan diterapkan pelatihan dengan metode pembelajaran orang dewasa yaitu pendekatan ceramah, diskusi dan praktek. Kegiatan Pengabdian kepada masyarakat dilaksanakan bulan Juli 2018 sampai dengan Desember 2018.

Metode Program dilaksanakan yaitu dengan kegiatan sebagai berikut.

1. Pelatihan kewirausahaan Materi pelatihan adalah kewirausahaan dan peluang usaha rumahan. Tujuan pelatihan ini adalah memberikan ilmu dan wawasan baru kepada ibu-ibu rumah tangga tentang wirausaha dan peluang usaha rumahan, sehingga terbuka pikiran serta tumbuh minat dan motivasi dalam diri mereka untuk berwirausaha.

2. Pelatihan pemasaran.

Materi tentang prinsip dasar pemasaran produk, bertujuan agar mitra mengetahui cara pengemasan yang baik, sehat dan menarik serta strategi pemasaran produk. Pelatihan ini disampaikan dalam bentuk ceramah dan tanya jawab kepada peserta.

3. Penyuluhan dan Pendampingan pengelolaan keuangan

Agar mitra dapat melakukan manajemen usaha yang baik dan dapat melihat perputaran modal dari keuntungan yang diperoleh, serta mengembangkan usahanya dan mitra memahami akan produksi makan sehat dan aman.

\section{HASIL DAN EVALUASI \\ Hasil \\ Persiapan}

Pada tahap persiapan tim kegiatan pengabdian masyarakat mengunjungi mitrauntukberdiskusitentangkesiapan mitra untuk menerima kunjungan tim, serta menetapkan waktu pelaksanaan kegiatan, dan disepakati kegiatan pelatihan tentang wirausaha dan pemasaran dilaksanakan pada hari Kamis, 9 Agustus 2018 bertempat di rumah Ibu Esust Seetiawati, SE, MM selaku Ketua Kegiatan Pengabdian Masyarakat ITB Ahmad Dahlan. 
Pelaksanaan kegiatan Pengabdian

Kepada Masyarakat.

Sosialisasi kegiatan dan

pendaftaran mitra

Di lingkungan RW 04 terdiri dari 5 RT, sehingga dalam kegiatan sosialisasi dan pendaftaran mitra, kami berkoordinasi dengan RT setempat, dan terdaftar 20 (dua puluh) peserta. Dari keduapuluh peserta kami identifikasi ada 10 peserta yang sudah memiliki usaha dan 10. Peserta belum memiliki usaha.

\section{Pelatihan}

Pelatihan kewirausahaan dan pemasaran diberikan kepada seluruh mitra, baik yang sudah memiliki usaha maupun yang belum memiliki usaha. Adapun tujuan dari pelatihan ini adalah untuk membangkitkan semangat berwirausaha bagi ibu-ibu rumah tangga dan menambah wawasan bagi mitra yang sudah memiliki usaha. Kami memberikan wawasan bagi mitra yang belum memiliki usaha, bahwa usaha dapat dimulai dari hal yang kecil dengan memanfaatkan peralatan yang ada. Misalnya memulai usaha menjadi agen pulsa dengan memanfaatkan handphone, menjadi agen tiket, menjadi agen bank dan lain-lain. Sedangkan bagi mitra yang sudah memiliki usaha dapat memperluas pasar dengan bermitra atau kerjasama dengan GoFood, GrabFood dan lain-lain. Pelatihan pemasaran kami sampaikan tentang pentingnya merek produk atau nama usaha, karena hal tersebut yang akan memudahkan pembeli atau konsumen dalam mencari produk atau warung/ tempat usaha.

\section{Penyuluhan dan pendampingan}

Penyuluhan dan pendampingan kami berikan kepada mitra yang sudah memiliki usaha dan berjumlah 10 mitra. Usaha yang sudah dijalankan oleh mitra adalah usaha dibidang kuliner, maka kami memberikan penyuluhan tentang keamanan pangan, dan pendampingan kami berikan dalam hal pengelolaan keuangan.

\section{Penyuluhan kesehatan dan keamanan pangan.}

Penyuluhan yang kami sampaikan adalah bahwa pangan/ makanan yang diproduksi dan dijual harus bebas dari tiga (3) cemaran yaitu cemaran biologis, cemaran kimia dan cemaran benda lain, serta penggunaan bahan pengawet, bahan pewarna dan penyedap, menggunakan bahan yang aman untuk dikonsumsi dan digunakan seminimal mungkin.

Adapun secara garis besar materi yang kami sampaikan adalah sebagai berikut.

1. Kewirausahaan: peluang wirausaha

Peserta mampu memahami pengertian wirausaha, mampu membaca peluang usaha dan memulai usaha

2. Pemasaran: Merek dan perluasan pasar

Peserta memahami pentingan merek (nama usuaha) dan kesempatan perluasan pasar.

3. Penyuluhan: Keamanan pangan Peserta dapat memahami pentingnya kesehatan dan keamanan makanan yang di produksi dan di jual

4. Pendampingan: Pengelolaan 
keuangan

Peserta mampu mengelola keuangan usaha dengan baik dan benar, sehingga dapat usahanya dapat berkembang dengan modal yang dimiliki.

\section{Evaluasi}

Mitra kegiatan ini adalah ibu-ibu rumah tangga, maka kami mengadakan evaluasi melalui pengamatan dan wawancara langsung, dengan hasil sebagai berikut.

1. Aspek Kewirausahaan

Indikator dari aspek kewirausahaan ini adalah mitra mampu mencari peluang usaha yang dapat dikerjakan dirumah dan berani memulai usaha. Jumlah mitra yang memulai usaha sebanyak 2 orang, yaitu usaha sebagai agen pulsa. Untuk mitra yang sudah memiliki usaha makanan rumahan, mitra sudah mulai mengembangkan variasi makanan.

2. Aspek Pemasaran

Indikator dari aspek pemasaran ini adalah mitra menciptakan atau membuat merek atau nama untuk tempat usaha. Jumlah mitra yang membuat nama atau merek untuk tempat usaha sebanyak 5 mitra.

3. Aspek Kesehatan dan Keamanan Pangan

Indikator dari aspek kesehatan dan keamanan pangan adalah mitra mengaplikasikan produksi makanan sehat, menghindari makanan dari cemaran biologi, cemaran kimia dan menjaga lima kunci makanan sehat. Mitra menjajakan makan tidak menggunakan alas kertas Koran dan menutup tempatmakanan : 10, Mitra dan mitra mengaplikasikan produksi makanan sehat : 3 mitra

4. Aspek Manajemen Keuangan Indikator dari aspek manajemen keuangan adalah mitra mencatat transaksi kegiatan usaha. Dengan alasan keterbatan waktu mitra yang melakukan pencatatan kegiatan keuangan : belum ada.

\section{SIMPULAN}

Hasik kegiatan pengabdian kepada masyarakat ini dapat disimpulkan bahwa:

1. Kegiatan ini dapat memberikan pengetahuan dan wawasan tentang peluang usaha bagi mitra khususnya ibu rumah tangga, dengan modal kecil dan menggunakan peralatan yang sudah ada, sehingga dapat menambah pendapatan keluarga.

2. Bagi mitra yang sudah memiliki usaha, merasakan manfaatnya dan mereka berencana untuk saling tukar makanan yang diolah untuk dipasarkan diwarungnya.

3. Mitraberencanauntukmembentuk kelompok usaha untuk saling mendukung dalam pemasaran dan keuangan terutama permodalan (simpan - pinjam).

\section{DAFTAR PUSTAKA}

Boone Louise E, Kurte David L, Pengantar Bisnis Kontemporer Edisi 13, Penerbit Salemba Empat Jakarta.

Hendro (2011), Dasar-dasar kewirausuahaan (Panduan bagi mahasiswa untuk mengnenal, memahami dan memasuki dunia 
bisnis), Jakarta, Indonesia, Erlangga

Hadiyati: Kajian Pendekatan Pemasaran Kewirausahaan dan Kinerja Penjualan Usaha Kecil Jurnal Manajemen Dan Kewirausahaan, Vol.11, No. 2, September 2009: 183-192

Kotler Philip, Keller Kavin Lane, Manajemen Pemasaran Edisi 13, Penerbit Erlangga, Jakarta.

Maria Saty Rani, Monika Teguh, Bulettin Bisnis dan Manajemen Universitas Ciputra Vol 2 nomor 2 tahun 2016, ISSN 2442 $-885 \mathrm{X}$

Rudiati Evi Masithoh, Heni Kusumawati, Pemberdayaan Ibu Rumah Tangga dalam Implementasi Teknologi Pengolahan Sumber Karbohidrat Nonberas dan Penganekaragaman Pangan Nonterigu untuk Mendukung Ketahanan Pangan Indonesian Journal of Community Engagement Vol. 02, No. 01, September 2016

Widiyono, Pakkanna Mukhaer, Pengantar Bisnis Respon Terhadap Dinamika Global, Edisi 2, Penerbit Mitra Wacana Media, STIAMI, Jakarta 